\title{
Monitoring of the Diffusion Processes during Carburizing Automotive Steel Parts
}

\section{Iva Nová, Jiri Machuta}

Faculty of Mechanical Engineering, Technical University of Liberec, Studentská 2, 46117 Liberec 1, Czech Republic. E-mail: iva.nova@tul.cz,jiri.machuta@tul.cz

The article deals with the prediction of diffusion process of steel components, respectively diffusion of carbon during carburizing. The calculation was made on the basis of the solution diffusion in semi-infinite space. For the calculation there was used the II. Fick's law. For the reason that the transfer medium is formed at the interface environments diffusion boundary layer, for the more accurate calculations, it is necessary to consider the coefficient of transfer of $\beta$ atoms of carbon. For the calculation of the diffusion coefficient $D$ was used Arrhenius's equation, which is based on the rate of diffusion processes (diffusion). It was calculated the time for diffusion of carbon to achieve the concentration of $0.8 \% \mathrm{C}$. There was also made a calculation of carbon diffusion in the gear from material EN DIN 1.7142 (DIN 14221). Diffusion was performed at $950{ }^{\circ} \mathrm{C}$, the initial concentration of carbon was $0.2 \%$. Carburizing carbon concentration was $1.1 \% \mathrm{C}$ and carburizing time was 1,3 and 6 hours.

Keywords: Carburizing, Diffusion, Carbon, Gearwheel, Calculation

\section{Acknowledgement}

This article is financially supported by Ministry of Education Youth and Sports of Czech Republic through the project $S G S$.

\section{References}

[1] TOTTEN, G. E. (2006). Steel heat treatment hand book. Metallurgy and technologies. ISBN 9780824727413 CAT - DK 3125.

[2] ASKELAND, D. R a Pradeep P PHULÉ. (2003). Science and engineering of materials. 4 th ed. Pacific Grove: Books/Cole-Thomson Learning, 1003 s. ISBN 0534953735.

[3] CALLISTER, W. D. (2003). Materials science and engineering: anintroduction. 6th ed.New York: John Wiley and Sons, Inc., 820 s. ISBN 0-471-22471-5.

[4] PISEK, F.et al. (1974). Nauka o materiálu I/1 (Science of material I/1) 1st. edition,(in Czech).

[5] DULCY, J,. BILGER, P, ZIMMERMANN , D. AND GANTOIS, M. (1999). Characterization and Optimization of a Carburizing Treatment in Gas Phase: Definitionof a New Process, In: Metall. Ital., 91(4), p 39-44

[6] STRANSKY, K. (1977). Termodynamika kvazistacionární difúze uhlíku v ocelích a její aplikace. 1. vyd. Praha: ACADEMIA, 148 s. (in Czech).

[7] MILLION, B., BACILEK, K., KUCERA, J., MICHALICKA, P., REK, A. (1995). Carbon Diffusion and Thermodynamic Characteristicsin Chromium Steels, In: Z. Metllkd., 86 (10), p. 706-712 (Materials Research and Advanced Techniques).

[8] KUCERA, J., STRANSKY, K. (2003). The Dependence of Carbon Diffusion Coefficients in Austenitic Ternary Alloys on Concentration of Additive Elements. In: Acta Tech. CSAV, 48(4), p. 353-364 (Ceskoslovenska Akademie Ved).

[9] KARABELCHTCHIKOVA, O., SISSON, R.D. (2006). Carbon Diffusion in Steels: A Numerical Analysis Based on Direct Integration of the Flux. In: Journal of Phase Equilibia and Diffusion. Vol. 27 No 6., p. 598 - 604.

[10]RIMMER, K. E., SCHWARZ-BERGKAMPF, E., WUNNING, J. (1975). Surface Reaction Rate in Gas Carburizing. In: Haerterei-Technische Mitteilungen, 30 (3), p. 152-160. 